\title{
Correction to: The association of prothrombin complex concentrates with postoperative outcomes in cardiac surgery: an observational substudy of the FIBRES randomized controlled trial
}

\section{Association entre les concentrés de complexe prothrombinique et les issues postopératoires en chirurgie cardiaque : une sous-étude observationnelle de l'étude randomisée contrôlée FIBRES}

\author{
Justyna Bartoszko, MD, FRCPC, MSc iㅣ • Jeannie Callum, MD, FRCPC • \\ Keyvan Karkouti, MD, FRCPC, MSc • the FIBRES study investigators
}

Published online: 18 October 2021

(C) The Author(s) 2021

\section{Correction to: Can J Anesth/J Can Anesth https://doi.org/10.1007/s12630-021-02100-4}

The article "The association of prothrombin complex concentrates with postoperative outcomes in cardiac surgery: an observational substudy of the FIBRES randomized controlled trial / Association entre les concentrés de complexe prothrombinique et les issues postopératoires en chirurgie cardiaque : une sous-étude observationnelle de l'étude randomisée contrôlée FIBRES" written by Bartoszko, Callum, and Karkouti was originally published electronically on the publisher's internet portal

The original article can be found online at https://doi.org/10.1007/ s12630-021-02100-4.

\footnotetext{
J. Bartoszko, MD, FRCPC, MSc ( $₫)$

Department of Anesthesia and Pain Management, Toronto General Hospital - University Health Network, Sinai Health System, Women's College Hospital,, University of Toronto, 200 Elizabeth Street, 3EN-464, Toronto, ON M5G 2C4, Canada

e-mail: Justyna.bartoszko@uhn.ca
}

Peter Munk Cardiac Centre and Toronto General Hospital Research Institute, University Health Network, Toronto, ON, Canada

J. Callum, MD, FRCPC

Department of Pathology and Molecular Medicine, Kingston Health Sciences Centre, Toronto, ON, Canada on September 14, 2021 without open access. With the author(s)' decision to opt for Open Choice the copyright of the article changed on October 5, 2021 to (C) (CThe Author(s) and the article is forthwith distributed under a Creative Commons Attribution-NonCommercial 4.0 International License, which permits any non-commercial use, sharing, adaptation, distribution and reproduction in any medium or format, as long as you give appropriate credit to the original author(s) and the source, provide a link to the Creative Commons licence, and indicate if changes were made.

The images or other third party material in this article are included in the article's Creative Commons licence, unless indicated otherwise in a credit line to the material. If material is not included in the article's Creative Commons

Department of Pathology and Molecular Medicine, Queen's University, Kingston, ON, Canada

K. Karkouti, MD, FRCPC, MSc

Department of Anesthesia and Pain Management, Toronto General Hospital - University Health Network, Sinai Health System, Women's College Hospital,, University of Toronto, 200 Elizabeth Street, 3EN-464, Toronto, ON M5G 2C4, Canada

Peter Munk Cardiac Centre and Toronto General Hospital Research Institute, University Health Network, Toronto, ON, Canada

Institute of Health Policy Management and Evaluation, University of Toronto, Toronto, ON, Canada 
licence and your intended use is not permitted by statutory regulation or exceeds the permitted use, you will need to obtain permission directly from the copyright holder.
To view a copy of this licence, visit http:// creativecommons.org/licenses/by-nc/4.0/

Publisher's Note Springer Nature remains neutral with regard to jurisdictional claims in published maps and institutional affiliations. 